\title{
Elizabeth Gaskell's early contributions to Household Words: The parabolic and the transformation of communities through "kinder understanding"
}

In a letter to Elizabeth Gaskell in January 1850, Charles Dickens praised Mary Barton: A Tale of Manchester Life (1848) for its ability to produce an emotional response. Requesting that Gaskell "write a short tale, or any number of tales” for his new two-penny weekly, he comments, "I do honestly know that there is no living English writer whose aid I would desire to enlist in preference to the authoress of Mary Barton (a book that most profoundly affected \& impressed me)” (Dickens Letters 6.21). Dickens was correct in his forecast that Gaskell's “short tales” would invoke the kind of response he sought. "Lizzie Leigh", which ran as the lead story in the first issue of Household Words in March 1850 and continued in the next two issues, reduced him to tears (ibid 6.48). It was tears that he solicited from his own fiction. As Mary-Catherine Harrison explains, he hoped that if "middle- and upperclass readers could vividly imagine the suffering they did not themselves experience [...] they would be moved enough to intervene” (263). Through an analysis of "Lizzie Leigh" alongside the two subsequent tales published in the journal, "The Well of PenMorfa” (Nov 1850), and “The Heart of John Middleton” (Dec 1850), this article explores how Gaskell extends and nuances Dickens’s investment in pathos by adapting the properties of biblical parable and by calling for the praxis that has its basis in devotional reading practices. By contextualizing the stories in Household Words, I suggest how they express the causal relationship between emotional response and action that underlies the objective Dickens had for the journal: "the raising up of those that are down, and the general improvement of our social condition” (Dickens Letters 6.21). 
Gaskell’s fiction differs from Dickens's in its enactment of, and its approach to, the "improvement of our social condition". Whereas Dickens's fictional pieces repudiate the "iron binding of the mind to grim realities", and ask that the poor labourer free himself from “self-reproach” (“Preliminary Word” 1, 2), Gaskell’s stories demand that readers confront "grim realities”. Rather than draw on the Romance tradition, they instead re-work the parable's unflinching diagnosis of the hearer's response to the suffering of humanity. As what follows will explain, Gaskell's engagement with the genre of parable underlies her recognition of the power of storytelling to promote the type of "kinder understanding" that emerges not from the softening properties of "Fancy" ("Preliminary Word” 1) but from the interpretive capacity of the self-critique that leads to praxis.

The repeated call to self-critique in Gaskell's short fiction harnesses the affective power that enables an engagement with the intense psychological suffering of lost women, prodigal children, the poverty-stricken, and exiles. "Lizzie Leigh” tells the story of a mother who, with her two sons, goes in search of her fallen daughter. The mother's fight to redeem her daughter from the self-ruinous path of prostitution appropriates the motifs of the prodigal son and encourages readers to respond to outcasts with the recognition that, since all share one humanity, all are responsible for the alleviation of suffering and oppression. While the action of this story begins on Christmas Day, the winter publication dates of the other two pieces that I focus on accentuate a concern with the benevolence associated with the Christmas season. In “The Well of Pen-Morfa,” the story of maternal love is repeated but to a different effect. Here, the protagonist Nest Gwynn learns to overcome the bitter despair which comes after a disabling accident by taking on a maternal role to the "poor half-wit" Mary (208). “The Heart of John Middleton” weaves yet another story of overcoming 
adversity by self-sacrifice and empathetic identification. Through a first-person confessional narrative, John tells of how his saintly wife Nelly enables him to replace a passion for vengeance with an ethic of compassion, forgiveness and reciprocity. The tale ends with the widowed John extending his wife’s message: "I am old now [...] I try to go about preaching and teaching in my rough, rude way; and what I teach is how Christ lived and died, and what was Nelly’s faith of love” (334).

Although Dickens did not appreciate the necessity of Nelly's death and “wish[ed] to Heaven [Gaskell's] people would keep a little firmer on their legs”, his comment that "The Heart of John Middleton" is "worked out with a vigor and truthfulness that very very [sic] few people could reach” (Dickens Letters 6.231) is indicative of the value he placed on Gaskell's narratives as purveyors of the kind of truth that he sought to convey through his own engagement with the Romance tradition. As Harrison comments, Dickens's adherence to this tradition enables him to produce a “version of fancy” that describes reality in a way that “engages readers” imagination and emotion” (270). While Dickens’s characterization of Harold Skimpole in Bleak House reveals his awareness that this technique risks failure (Harrison 265), Gaskell's use of the rhetorical properties of parable to unpack the "truthfulness" in the interface between the sacred and secular ameliorates the anxiety that fiction about suffering will not in fact prompt benevolent action. ${ }^{1}$

While recent critical work has addressed the reading practices that are exploited through serial publication, little attention has been paid to the common ground between the development of the realism genre, the rise of the periodical and the concurrent surge in short stories, and the growing demand for devotional material. Bridging this gap, I want to stress Gaskell’s keen awareness of the wider “printmediated, national religious community” that Joshua King identifies in his article on 
the popular reception of John Keble’s Christian Year (397). In addition, I wish to explore how Gaskell's stories use the properties of parable as they call on the biblically informed middle-class readers of the journal to embrace devotional reading practices that are characterized by self-critique. While the first section of this article suggests how the stories depend for their effect on their publication context and awareness of audience, the second examines the contemporaneous practices of devotional reading that they dramatize and which, as a Unitarian, Gaskell would have performed herself. The third and final section then offers close readings that demonstrate how the stories themselves can be read as parabolic. Through these readings, I explore how Gaskell's ability to produce the response she hoped would lead to action stemmed from her investment in models of self-scrutiny, sympathetic identification, and quiet heroism.

\section{Wrapped up in Household Words}

Although Gaskell expressed to Harriet Martineau her dislike of "writing a long story to be broken up into little bits in a serial publication” (Further Letters 227), she did not fail to grasp the opportunities offered by serializing her short stories in Household Words alongside topical articles, poems, and essays. While “Lizzie Leigh” appeared over three weekly installments, “The Well of Pen-Morfa” appeared over two, and “The Heart of John Middleton” was published as a single self-contained tale. As Linda K. Hughes and Michael Lund note in their discussion of “Lizzie Leigh”, Gaskell responds to the demands of periodical publication by maintaining a "balance between 'connectedness' and suspense, self-containment and anticipation as forms of narrative pleasure” (98). They emphasize how, rather than plot-based, this balance is created by a focus on relationships and registers the significance of the way in which 
the first installment of "Lizzie Leigh" looks forward "not to an event but to a conversation” (ibid). I suggest that the dialogic bias of Gaskell's fiction connects with Dickens’s concern that “reader and writer [of Household Words] are conversationally bracketed together as having like interests and attitudes” (Lohrli 8). The embedded or wrapped up - position of her stories within the journal sets up a dialogue with the surrounding pieces and enables the parabolic gestures of characters to reach beyond the page in the challenge that readers translate their emotional response into care for the real-life groups of people that the fictional characters represent.

Appearing as the first item in the first issue of Household Words, Dickens's “A Preliminary Word” adopts the first person plural and establishes a conversational relationship between periodical and reader. As the journal's “conductor”, Dickens offers the promise that the content will nourish the imagination: it will "tenderly cherish that Light of Fancy which is inherent in the human breast" and "show to all, that in all familiar things, even in those which are repellant [sic] on the surface, there is Romance enough, if we will find it out” (1). In his 2009 monograph on the publishing history of Cranford, Thomas Recchio notes the absence of critical work that compares Dickens’s language of “Romance” with the language of another preliminary word, the 'Preface' to Gaskell’s Mary Barton” (33). Attention to the interface between Dickens’s “Preliminary Word” and Gaskell’s “Preface” reveals a shared faith in the power of imaginative writing to prompt compassion in lived experience. Considering Gaskell’s avowed purpose of fostering “deep sympathy” for the working classes (Mary Barton 3), Recchio comments on her optimistic faith that "readers will surrender themselves to the story, reflect on the texture of the lives of those depicted, and then perhaps [...] act in accordance with the new knowledge they will have acquired from the subjective experience of reading” (36). True to the 
promise of the Preface, it is through an extended engagement with the lives of the “care-worn” that the content of Mary Barton calls on readers to extend sympathy and exert a kindness that transcends the rationale of present ordinary experience (Mary Barton 3). While the sympathy that Gaskell calls for from her readers anticipates the “one sympathy” that Dickens hopes Household Words will foster ("Preliminary Word” 1), her contributions to the journal nuance his engagement with the Romance tradition by their biblically-based prompts to self-critique.

Dickens chose to include "Lizzie Leigh" as the first item in the first issue of the journal because, as Recchio comments, he found it to be "the most apt statement at the moment of publication to capture the essence of his ambitions” (33). One reason for its aptness is that it provides an accessible route to the kind of affective response that Dickens believed would lead to “a kinder understanding” among readers ("Preliminary Word" 1). In the obituary of William Wordsworth that he contributed to Household Words in May 1850, William Weir’s comment that Wordsworth “would almost appear to have lived 'among men, not of them'” (210) distances the realism of Lyrical Ballads from the kind of "truthfulness" that Dickens valued in Gaskell. Despite his dislike of her tendency to kill off her characters, his inclusion of her stories in the journal indicate his recognition that they are emphatically "of” men in the sense that they emerge from an engagement with the "grim realities" of lived experience and call on the reader to glimpse the human situation - as it sits between the everyday and the transcendent - more clearly (see above).

The immediacy of Gaskell's early contributions to Household Words is accentuated by a response to topical issues and a sensitivity to their place in a periodical which is, by definition, “an urban form - sharing the scale, diversity, fragmentation and anonymity of the metropolis” (qtd in Waters 7). One topical issue 
that Gaskell treats in all three stories is the harsh institutionalism of the workhouse system. Following his effort to "tarnish" the public image of the New Poor Law in Oliver Twist (Keen 38), Dickens exposes the horrors of the workhouse in two articles he wrote for Household Words in May 1850. In the first, he offers an unfavorable comparison between the provision for paupers in the Saint Pancras Workhouse and the treatment of criminals in Pentonville Prison ("Pet Prisoners" 98). In the other, he comments on the lack of liberty, food and kindness in the workhouse (“A Walk” 207). ${ }^{2}$ When Gaskell's stories are read alongside these pieces in the first volume of the journal, the aversion to the workhouse expressed by Susan in "Lizzie Leigh", Nest in "The Well of Pen-Morfa”, and John in “The Heart of John Middleton”, is shown to be well-grounded in the editorial campaign of uncovering injustice and accentuating the urgent need for an “improvement of our social condition” (Dickens Letters 6.21).

In a discussion of the unique place of Dickens's journals in the mid-Victorian literary marketplace, Lorna Huett draws attention to the format of Household Words and All the Year Round. Ordered in columns and printed on thin paper, both periodicals share properties with the newspaper (73). The process of reading a fictional tale alongside social observations on urban poverty means recognizing how fiction jostles with the words of the everyday world. In "Lizzie Leigh” the space between newspaper and fictional narrative is closed as motifs from melodrama are brought into the domestic space of the household. At the climax of the story, foster mother Susan finds an obstruction blocking the doorway of her house: "she immediately recognized the appearance of a little parcel, wrapped up in a scrap of newspaper, and evidently containing money” (63). While Hughes and Lund suggest that this reference effectively "wraps Lizzie and her child in different words” (75), its 
inclusion also gestures toward the story's wrapped up place in a journal comprised of eclectic miscellany.

Immediately following the first installment of “Lizzie Leigh”, Dickens includes the piece, "Valentine’s Day at the Post Office”. Co-written with assistant editor W.H. Wills, it describes how the Post-Office is organized. In it, we are told, the news of "all the civilized earth” is "heaped up, parceled out, carried about, knocked down, cut, shuffled, dealt, played, gathered up again, and passed from hand to hand” (9). According to Caroline Reitz, the "orderly system underneath seeming disorder" offers a meta-reference to the contents of the journal itself (38). She comments on how Dickens highlights the Post-Office’s ordered system and "connects it with the work of bringing into the English home the 'stirring world' around it in the form of the newspaper” (ibid). Within a world of production and consumption, Dickens anticipated that Household Words would enable discerning readers to develop selfknowledge through an engagement with the apparently haphazard ordering of the content of each issue and volume.

Printed on the same page as the final installment of "Lizzie Leigh" is an essay that reinforces this sense of searching for hidden order and unity beneath apparent chaos. Written by William Weir and W.H. Wills, "Short Cuts Across the Globe” celebrates the canals, railways, and ships that enable trade and communication between cities and countries. It concludes with a shift of focus as it moves from descriptions of modern invention to a concern with the transformation of society. Anticipating the interest that "the friends of Christian missions, and the advocates of Universal Peace among nations” will have in Prince Albert's description of the “forthcoming great Exhibition of Arts and Industry” (67-8), the authors incorporate a long quotation from his speech regarding the way in which "modern invention” brings 
together "different nations and parts of the globe” (68). Building on Reitz's discussion of how Prince Albert's plan for the Exhibition echoes Dickens's initial explanation of the purpose behind Household Words” (26), I want to suggest how Gaskell contributes to the journal's ongoing conversations by offering stories that move the reader from an assessment of the nation to intense self-scrutiny. The section that follows argues that the success of these stories and of the journal's avowed project of transforming society through "kinder understanding" - depends on readers who are familiar with the rhetorical power of parables and who are attuned to making connections between what they read and how they live in community.

\section{Devotional reading and Unitarian values}

In a letter to the American author and critic Charles Eliot Norton in 1859, Gaskell expresses her longing for "some really spiritual devotional preaching instead of controversy about doctrines, - about whh [sic] I am more \& more certain we can never be certain in this world" (Gaskell Letters 418). This remark is indicative of her strong dislike of Utilitarian principles and “dogmatic hard Unitarianism” (Gaskell Letters 84). For Gaskell, what is truly devotional cannot be explained by reason or parceled up in a sermon for the sake of instruction. She represents this belief in Ruth when dissenting minister Mr. Benson dispenses with the sermon on which he had "laboured hard” and instead "opened the Bible, and read the seventh chapter of Revelations, beginning at the ninth verse" $(455,457-8)$. While the three stories that I have chosen to focus on model this kind of heartfelt preaching, they do so in the more informal context of conversation and dialogue. When they are re-printed together at the start of the Cheap edition of Lizzie Leigh and Other Tales (1855), they look back to the conclusion of Ruth (which is mentioned on the title page) and anticipate the 
passionate "preachment" for which the character Libbie Marsh is mocked in a tale that Gaskell republished towards the end of the volume (252). ${ }^{3}$ Rooted in conversation, the preaching that Gaskell models through Anne Leigh, David Hughes, and John Middleton comes from a similar desire for justice and brings a sense of the transcendent to the everyday. By avoiding certainties, their “preachments” presuppose the possibility of multiple meanings and echo the parable's prophetic challenge to the reader to apply the message to their own circumstances.

In her book, Victorian Parables (2012), Susan Colón explains that the Greek word parabole, which signifies “throwing alongside”, came to "refer to comparison of one thing to another by proximity and contrast” (3). Looking back to the Judaic roots of the genre, she comments that while the Hebrew word "mashal (from the root msl, meaning "to be like" and translated parabole in the Septuagint) carried a very wide range of signification”, it nonetheless "clarifies essential similarities of technique that underlie otherwise divergent literary and rhetorical effects” (3-4). She explains how some of these key features of parable are exemplified in 2 Samuel 12.1-7, which describes how the prophet Nathan confronted David over his adultery with Bathsheba and his murder of her husband Uriah. Suggesting how the story Nathan tells David works as “an indictment of sin, a condemnation of a man’s grave transgressions against justice,” Colón writes:

The parable is directed against the powerful, to one perhaps inclined to see himself as master of the Law rather than as accountable to it. [...] the analogical approach to the judgment against David disarms his self-protective justifications, eliciting from the king himself a condemnation that would not be permitted against the king in the mouth of another. This analogy between 
the story and the life of the hearer is brought home in an unexpected reversal that brings self-recognition [...]. Finally [...] the complete interpretation of the parable occurs in David's embodied response, a response which takes the form of acts and words of penitence. (5)

Commenting on how Jesus's parables arise out of the tradition that Nathan's story exemplifies, Colòn suggests how they invite hearers and readers to "think very differently about something one thought one knew" and also "to act very differently, according to a new construal of reality” (7). In her subsequent readings of novels by Charlotte Yonge, Margaret Oliphant, and Charles Dickens, she considers how parables are transposed into realist fiction to illuminate ethical and religious concerns. In a recent article on the function of parables in Mary Barton, Amy Cote extends Colòn's emphasis on how novelists borrow the parable’s call for the kind of “embodied response” that David models. After considering how Victorian authors and artists re-script the biblical text in order to convey the counter-cultural and subversive place that the New Testament parables held for Jesus's first hearers, Cote explains how the parable's "true exegesis [...] exists not within the text but as an extra-textual event, a perlocutionary act demanding praxis rather than merely intellectual comprehension” (00). Her reading of Mary Barton as a "catalyst text” (00) unpacks some of the ways in which Gaskell draws on the rhetorical properties of the biblical parable and demands from readers "self-examination and action" (00). In extending the work of Colón and Cote and shifting attention from the novel to short fiction, I contend that “Lizzie Leigh,” “The Well of Pen-Morfa” and “The Heart of John Middleton” can be understood as "catalyst texts” in the way that they call for accountability, forge out spaces of sympathetic identification, and invoke the kind of 
response evident in David: self-reproach, penitence, and a complete change of position.

In unpacking what he terms “the jouissance of belief”, Liam Corley describes the practice of devotional reading in terms of a "radical surrender to divinely-inspired textuality in pursuit of transcendent union” (255). He argues that the relation of this practice to accountability and self-critique is "expressed in the questions a reader asks of the biblical text, questions that presuppose the insufficiency of the reader and the plenitude of the text when read in light of divine inspiration” (257). What I want to suggest here is that Gaskell's re-inscriptions of the parables of the Prodigal Son and the Good Samaritan work to emphasize "the insufficiency of the reader” as interpreter as they call for increased self-reflection. Although not dismissing the validity of Jon Singleton’s account of how Gaskell’s biblical allusions engage with “ongoing social conflicts where scriptural authority was being used as cultural and even political weapon” (918), I contend that the allusions speak less to social conflicts than they do to the dynamics of individual relationships and the concern with the penitent reader's self-critique and change of position.

While Gaskell had associations with the liberal wing of Unitarianism that can be traced back to James Martineau's The Rationale of Religious Inquiry (1836), her Unitarian faith remained firmly in the Biblicist tradition. ${ }^{4}$ Timothy Larson indicates the huge public demand for material that conformed to this tradition by stressing how Mary Carpenter’s Morning and Evening Meditations (1845) sold out within a few months and quickly went through 6 editions (155). The volume begins with a meditation on Lamentations 3.40: "Let us search and try our ways” (1). An emphasis on the work of self-sifting is carried through each entry with the object of changing social relations through the transformation of the individual. Whereas the broadly 
Catholic practice of devotional reading is based on the premise that readers invite the Holy Spirit to convict them of sin and to guide them into truth, the Unitarian tradition that Carpenter popularizes is reliant on the individual testing the truth of Scripture through the lived experience of relationships. As R.K. Webb explains, the Unitarians prioritized "the bringing together of superior and inferior in a common humanity [and] the transmission of powerful moral influence in a one-on-one relationship” (147). Gaskell's commitment to this model and to the transformation of society at the individual and dialogical level rather than the institutional is indicated by the domestic settings of her short stories and through the sharp convictions that her characters experience when, like David, they are held accountable by an analogical narrative that demolishes faulty perception.

\section{Reading the stories as parables}

Dickens concludes “A Preliminary Word” with the encouragement: "The road is not so rough that it need daunt our feet [...] Go on, is all we hear [...] go on cheerily” (2). In the first paragraph of "Lizzie Leigh," which is printed directly below these lines and given the subheading “A Domestic Tale,” the father's dying words of forgiveness indicate the possibility to "go[ing] on" in spite of the "utter blackness" of the circumstances (2). Although we are told that the presence of death on Christmas Day "gives a poignancy to sorrow”, the sound of the church bells signals what remains unsaid: the transcendent hope that the Incarnation brings.

The narrative of "Lizzie Leigh" expresses the tension between ordinary lived experience and transcendent hope as it moves from the scene of James Leigh's death to offer a picture of the newly bereaved family. Reflecting on her husband's 
forgiveness for their fallen daughter Lizzie, Anne asks her youngest son to "read me the Prodigal Son":

Tom found the chapter, and read it in the high-pitched voice which is customary in village-schools. His mother bent forward, her lips parted, her eyes dilated; her whole body instinct with eager attention. Will sat with his head depressed, and hung down.

He knew why that chapter had been chosen; and to him it recalled the family’s disgrace. When the reading was ended, he still hung down his head in gloomy silence. But her face was brighter than it had been the day before. Her eyes looked dreamy, as if she saw a vision; and by and by she pulled the Bible towards her, and putting her finger underneath each word, began to read them aloud in a low voice to herself; she read again the words of bitter sorrow and deep humiliation; but most of all she paused and brightened over the father's tender reception of the repentant prodigal. (3)

While Tom with his village-school voice is representative of the rote learner and his older brother Will is representative of hard-hearted cynicism, Anne embodies the ideal devotional reader. By repeating the words, pausing over them with her finger, and brightening over the memory of the father's "tender reception" of his son, she recognizes their analogical significance. As her subsequent discussion with Will reveals, she is led by devotional and spiritual feelings which transcend the rational. Justifying her plan to move to Manchester to seek Lizzie, she recalls: 
“Many's the time I’ve left thy father sleeping in bed, and stole to th' window, and looked and looked my heart out towards Manchester, till I thought I must just set out and tramp over moor and moss straight away till I got there, and then lift up every downcast face till I came to our Lizzie.” (4)

In spite of the apparent hopelessness of her search, Anne takes strength from the extraordinary picture of forgiveness and homecoming offered in the parable. Just as the father is described as running to meet his son while he was "yet a great way off" (Luke 15.20), Anne’s compassion for Lizzie overrides any sense of ordinary decorum. While her husband James had refused to admit his daughter as kindred (4), Anne reveals a willingness to share her daughter's humiliation: to "tramp” in the same path and to spend her evenings in Manchester walking in the shadows along the dark routes taken by prostitutes (5). The description of Anne’s shadowy but compassionate presence recalls the hope that Dickens's expressed to John Foster as he planned the journal: that it would function as a "certain shadow" and become "a kind of semiomniscient, omnipresent, intangible creature” (Dickens Letters 5.622). Entering dark and forgotten places, Anne’s night wanderings work to extend Dickens's objective of “dispos[ing]” middle-class readers to form “a better acquaintance” with their poorer neighbors (“Preliminary Word” 1).

Will's opposition to his mother's search is indicative of the legacy of his father’s "stern anger" (4). When the description of how he thought about Lizzie "sometimes, till he ground his teeth together, and could have struck her down in her shame” is read alongside Dickens’s story, “A Child’s Dream of a Star”, which was published in Household Words alongside the second installment of “Lizzie Leigh”, the incompatibility of Will's attitude with the journal's vision of bringing about a 
“kinder understanding” is illuminated (“Preliminary Word” 1). Dickens’s story recounts a boy's journey into manhood. After the death of a younger sister, he determines to look up to the star where he believes that she has gone and to make his "Home” there (25). As he grows older and suffering softens his heart, his love for his sister remains unfaltering. When Gaskell's story is read alongside this representation of sibling love, Will's hard judgment towards his younger sister is accentuated and, after the pattern of parable, his words prompt the reader to assess her own attitudes. Moreover, Anne's emphatic comment that if Will's beloved Susan Palmer could show "no pity” for such as Lizzie she would be a "cruel Pharisee” (32) accentuates the distinction between those who are transformed by Jesus's parables and those who remain hard-hearted.

Gaskell’s parabolic warnings against Pharisaic judgment are sharp and insistent. However, what is less orthodox in her fiction is that the voice of authority is feminine. Rebuking Will's anger at his sister with a newly discovered spiritual authority, Anne dares “to command” him with the knowledge that "I am in the right and that God is on my side” (61). In her rebuke, she stands not "as the meek, imploring, gentle mother, but firm and dignified, as if the interpreter of God's Will” (ibid). This emphasis on her assumed authority contravenes the Miltonic rule that had guided her in married life: that her husband "was truly the interpreter, who stood between God and her” (2). As a figure of spiritual authority, she stands "as if” she were a prophet and challenges the tradition that sees this role as male. As Christine Krueger comments, her words render her "no longer a mother subservient to her adult son, but a 'Mother in Israel'” (Krueger 168). While Anne’s words contribute to Will’s transformation, it is the words of Susan that eventually soften his heart. Described by Anne as a woman "too deep read in her New Testament” to "judge and scorn the 
sinner”, Susan serves as the mediator through whom Will comprehends the transformative power of the Word (61). For her, as for Anne, the activity of reading is a devotional and creative act. The description of being "deep read” is indicative of what Colòn describes as a propensity to an “embodied response” (5). Susan’s love of Lizzie’s baby and her concern with keeping her from the horror of growing up in the workhouse links to the other pieces in the journal that critique of the impersonal provision of the New Poor Law. By responding to Susan's doctrine of love with the admission, “Thy words cut me”, Will reveals how her embodiment of the message of forgiveness impels his repentance (64). Significantly, this repentance is more than sorrow and penance; it denotes the "change of mind" that is the obsolete definition of the word $(O E D)$. What Gaskell models through him is the radical change which an accountable reading of Scripture engenders.

Not only does Gaskell use Will to critique entrenched attitudes to the fallen woman but she also corrects Anne’s misapprehension that the only possible outcome for the fallen woman is death. After discovering that the baby Susan claims as her "niece” is actually the daughter of Lizzie, Anne echoes her wish to find her lost daughter: “Oh, if we could but find her! I’d take her in my arms, and we’d just lie down and die together” (34). Susan gently rebukes this wish with the affirmation that Lizzie, like Mary Magdalene, “may turn right at last” (34). In this recognition of the Magdalene's redemption, she echoes the words of Anna Jameson who, at the close of the first of her two hugely popular and culturally significant volumes, The Poetry of Sacred and Legendary Art (1848), had deplored the move to "dethrone” the sinner turned saint. Jameson comments, “Poets have sung, and moralists and sages have taught, that for the frail woman there was nothing left but to die; or if more remained for her to suffer, there was at least nothing left for her to do: no choice between 
sackcloth and ashes and livery of sin” (1.387). While this belief informs traditional representations in art and literature, Emily Jane Morris explains that the death of the fallen woman does not necessarily cohere with historical evidence but instead fits with the expected trajectory of the traditional narrative (42). Whereas Ruth is about a fallen woman herself, "Lizzie Leigh" is less about the fall of the title character than about the interpretation of the narrative of fallenness. In terms of its correspondence with parable, it is less about the prodigal son than it is about the response of his older brother.

The tale's rootedness in the domestic space is illuminated by its inclusion of an extract from a poem by Barry Cornwall (aka Bryan Waller Procter). The verse is quoted to express how Nanny’s place in Susan’s heart will never be “usurp[ed]” (63). Like the poetic epigraphs in Mary Barton, Cornwall's poem instructs the reader how to feel and situates the text of the story in Dickens's wider network of writers. The fact that Cornwall had contributed his dramatic poem, “A Dialogue of Shadows”, to the previous issue of Household Words is significant in underlining Dickens' insistence that his journal would function as a "certain shadow" and the conversational dynamic of its community of writers and readers.

Concluding the third and final installment of the story, Gaskell brings the narrative up to the present day of her readership. Her narrator records how the Leigh family returned to Upclose Farm and speaks of how Anne and Lizzie now "dwell in a cottage so secluded that, until you drop into the very hollow where it is placed, you do not see it" (65). From here, Lizzie works for the good of her community and "comes out of her seclusion whenever there’s a shadow in any household” (65). As a result, “Many hearts bless [her], but she - she prays always and ever for forgiveness - such forgiveness as may enable her to see her child once more” (ibid). Rather than read 
Lizzie’s repentance in terms of a resistance to self-assertion, I suggest that an engagement with Gaskell's Unitarian commitment indicates that her emphasis on the turn to self-abnegation can be understood in a more positive way. In her reading of Gaskell’s later story, “The Poor Clare”, Rebecca Styler comments on the significance laid on the Unitarian principles of agency and personal responsibility. Rather than representing the end of the story - which sees Bridget's "constant service” to others in the community of Poor Clares - in terms of an integration into a patriarchal structure, she reads her self-emptying as an assertive grasping of salvation (96). Applying Styler’s discussion to a reading of “Lizzie Leigh” means understanding Lizzie’s dedication of herself to the service of others in terms of her journey towards what Unitarians saw as the redemption of the self through action and good works. By striving to forego self-interest, the reformed Lizzie exemplifies the charitable qualities of Unitarianism that had led Dickens to Edward Tagart's Little Portland Street Unitarian Chapel in 1842 (Dickens Letters 3.455-6; Cunningham 259). Ultimately, she stands as an apt emblem for the journal which he envisaged would work as a shadowy presence to engender charity and tolerance among readers.

Appearing directly after the third installment of "Lizzie Leigh" and before "Short Cuts Across the Globe” is a poem by William Cox Bennett entitled "The Seasons". Recognizing how the pieces in each journal issue "implicitly comment on each other,” Recchio suggests how this poem “serves as a meditation on [Gaskell's] story" (41). In the space of sixteen lines, the subject grows from a "blue-eyed child" into “an aged woman”. Considering the references to the "glossy spaniel”, Recchio comments on how the class bias of the poem contrasts to the working-class world of “Lizzie Leigh” (ibid, 42). He argues that this contrast "seems to ask the reader to consider what it was that prevented Lizzie’s life from following the conventionality of 
the poem, and perhaps to consider the heroism involved in Lizzie's efforts to fulfill as many of the conventions as she could” (ibid). Adding to this, the contrast between the trajectory of the story and the poem highlights how unconventional Lizzie’s final turn to self-abnegation actually is.

The theme of self-abnegation and the recognition that acts of extraordinary kindness can emerge from the shadows of dire circumstance runs through "The Well of Pen-Morfa”, the second piece that Gaskell contributed to Household Words. Gaskell sent Dickens the story in October 1850. Published in two installments one month later, it invites the reader into its world by describing a rural landscape and by giving directions as to its location. After a lengthy description of the cottages in the “Welsh Welsh village [sic]” of Pen-Morfa, her narrator situates herself and her readers as modern and English: "I could tell you of a great deal which is peculiar and wild in these true Welsh people, who are what I suppose we English were a century ago” (182). This comment anticipates the parabolic reversal that comes later in the story and extends the sense of a national English readership that is offered in Henry Morley's essay that opens the issue. Celebrating free speech, Morley suggests that the newspaper has overtaken the church in teaching "Christian doctrines” such as “tolerance” and “charity” (170). He concludes his survey of the changing nation with a move from judgment to self-reflection: "let us, in England, do our part; let us find out our faults and mend them” (172). Following Morley’s essay, Frederick Knight Hunt's story, “What a London Curate Can Do If He Tries”, recalls the history of an ordinary man who, through years of perseverance and kindness, becomes a recognizable "living hero" (176). It is this type of individual quiet heroism that is celebrated through “The Well of Pen Morfa”. Here, the pairing of the clergyman with Nest Gwynn reveals the opportunities for charity that exist in each sphere. 
Despite her promise to "hasten on to my tale" of Nest (182), the speaker calls on the reader's patience as she diverges and recollects a brief encounter with an elderly woman who in her youth had been sent to London before falling pregnant. She had returned to her home in Pen-Morfa to live a lonely existence as a solitary mother hiding away her "deformed" child (ibid). Extending the perception that charity is fostered in an individual when she identifies with the suffering of another, the embedded story that follows contrasts the social isolation of this mother with Nest's response to the lesson of self-sacrifice that she is taught by her own mother Eleanor and the visiting preacher David Hughes.

The end of the first installment describes Eleanor's visit to Edward, the man who proposes to her daughter Nest because he is attracted by her beauty but then rejects her after her debilitating accident for the ostensible reason that she will not be strong enough for farm-work. After listening to his pathetic excuses, Eleanor exclaims, “Though her body may be crippled, her poor heart is the same - alas! - and full of love for you” (185). Despite her initial wish for vengeance (for which she quickly repents), Eleanor's willingness to perform the necessary farm-work for Edward in her daughter's place recalls the maternal agency of Anne in "Lizzie Leigh" and is held up as a model of self-sacrificial love.

The second installment of “The Well of Pen-Morfa” is preceded by Eliza Griffiths’s poem, “The Dumb Child” (205). The poem’s narrative recalls Eleanor’s sacrificial maternal love in the depiction of a mother's struggle to overcome the sorrow that she feels on behalf of her deaf daughter. The poem traces how she and her husband come to accept and love their daughter's “voiceless eloquence”. The clear message that runs throughout is that the language of love runs deeper than speech and that God can bless with "beauty" features that might otherwise be perceived as a 
"defect” and as a challenge the emerging notions of "normalcy" that, according to disability theorist Lennard Davis, were coming “into consciousness” over the period 1840-1860 (Davis 24). The positioning of the poem before Gaskell’s story situates the reader in a posture of devotional reverence and calls on her to proceed with the narrative of Eleanor and Nest in a way that remains attentive to the integral value of those who differ from the "norms" that were beginning to be set by an industrial society concerned with usefulness and utility of each subject.

At the start of the second installment, we are told how Nest "halted on a crutch” and became "pale with suffering” (205). It is, however, her emotional anguish rather than physical impairment that is foregrounded as a disability. Unable to find an outlet for her grief, she becomes hard and proud. When David Hughes appears at the time of her mother's death, he looks beyond her pride and recognizes in her a potential for kindness, thus opening up the possibility of a different future. By describing David in the simple terms: "he suffered long and was kind" (207), Gaskell recalls 1 Corinthians 13.14: "Charity suffereth long, and is kind”. In line with the biblical text, his kindness comes in the form of a prophecy and a hard challenge. After praying, he tells Nest:

Henceforth you must love like Christ; without thought of self, or wish for return. You must take the sick and the weary to your heart and love them $[\ldots]$ I do not pity you [...] You are powerful enough to trample down your own sorrows into a blessing for others; and to others you will be a blessing; I see it before you; I see in it the answer to your mother's prayer. (208) 
For Nest, as for David, sympathy for the other is distinct from pity. It involves a willingness to be completely "trampled" down in order to take on the role of mediator between God's mercy and the world's desperate need.

When David Hughes returns to Pen-Morfa for a second time and learns that Nest has begun on the journey he advised her to take by caring for the "half-wit" Mary Williams, he admits that he had never before thought of learning the name of the "poor crazy creature" (208). Rather than seeing Mary - as others did - as a "wild beast” (208), Nest's validation of her need for affection and kindness brings her firmly into the Welsh community. Moreover, the recognition of Mary’s surname as Williams places her firmly into the world of Pen-Morfa's interchangeable surnames (182) and signals that she has replaced Edward Williams as an object of affection for Nest. The story concludes by describing how, when she is sent to the workhouse upon Nest's death, Mary strives to "curb her insanity” when she hears the name of her old mistress mentioned (210). As the legacy of Nest's kindness reaches beyond her lifetime and into the space of the workhouse, Gaskell consolidates the relationship between text and reader and hints at how her tale of transformation carries the propensity to reach beyond the pages of the periodical. Together with "The Dumb Child,” it works in the journal to challenge its audience to look past surface appearances. Its repeated emphasis on neighbors and neighborliness invites readers to ask with the recipient of Jesus’s parable of Good Samaritan, “who is my neighbour?” (Luke 10.29). The response that runs through Gaskell's stories and the surrounding content in the journal is that the most profound social change is not necessarily effected by those who are male, middle-class and able-bodied.

In "The Heart of John Middleton”, which appears in Household Words as a single installment in the issue for December 28, 1850, Gaskell addresses the parable 
of the Good Samaritan in more explicit terms and exemplifies the nature of selfless altruism. The persistent conflation of the narrator John's wife, Nelly, with Christ signals recognition of the power of kindness over evil. It is Nelly's "faith of love” that conquers John’s heart (331). Like Nest, Nelly reverses entrenched expectations and enacts the self-sacrifice upon which Gaskell suggests true personhood is based. John perceives that he was enabled to respond to her kindness by a "little golden filmy thread" which was woven into his life by "God's mercy" (326). The end of the story sees him determine to share this mercy as he extends her "faith of love” (334) and her embodiment of what it means to “love one’s neighbour as thyself” (Luke 10.27).

“The Heart of John Middleton” is published in a single installment in the Household Words issue and sandwiched between George Meredith’s poem, “New Year’s Eve” and [Mr.] Harper’s poem “The Chords of Love”. While Meredith’s poem asks the reader to look forward to the New Year as a time of abundant "charity" when pride will be cast off and the slave will be made free (325), Harper's emphasizes the value of deep affection and invites readers to look behind the surface of "quickmoved feelings” (334). Although "The Heart” shares a sense of hopefulness with these poems, its challenge to the reader cuts deeper. Rather than simply instruct readers to cast off "pride” as Meredith does, Gaskell uses the rhetorical properties of parable to prompt readers to critique their place within a global society where slavery is permitted and the needs of the hard-working pauper remain unmet.

John Middleton begins his confessional narrative by inviting the reader to enter into his world as he describes the peculiarities of the Lancashire village of Sawley. The convergence of past and present is rendered visible by the assortment of old cottages built from the stones of a medieval abbey and the new houses and factories "built still more recently" (325). The mismatch of architecture reflects 
John's unsteady progress through life. He recounts his earliest memories as ones of suffering and pain. Recounting his father's abusive and drunken behavior, he explains why he grew up with a "hating heart" (326). It is not until he meets Nelly, who is at this time a young girl, that he is inspired to look beyond his commonplace circumstances and hope for a kinder future for himself and for his society.

Rather than apportion blame for social injustice at an institutional level, Gaskell reveals the culpability of the indifferent middle-classes at an individual level. This culpability is exacerbated when John uses the language of the Good Samaritan to describe how, when he "fainted and bled, and found no man to pity or help me," relief came from an unexpected quarter: from "poor old Jonah, the publican and sinner" (330). Situating the poacher Jonah as the Samaritan means likening the middle-classes to the priest and Levite. This startling analogical configuration is indicative of Gaskell's hope that her story will work as the kind of "catalyst text” that Cote describes in the way that it reaches beyond the page and calls for application (Cote $00)$.

During the time that John is persecuted by the son of the factory overseer and watches as "honest folk [stand] aloof” from his suffering because of his criminal father, he pursues a course of reading that includes The Pilgrim's Progress and Paradise Lost (328). Lacking the "knowledge which would give a clue to all," or the kind of devotional imagination that would enable him to apply the allegories to his own circumstances, he continues to be driven by a "great passion of hatred" against the overseer’s son (328). John’s “passion of hatred” towards Dick Jackson is contrasted with Nelly's ethic of forgiveness. Nelly is held up as the ideal devotional reader: as a child, she recites "Our Father" with a "soft” and "holy” voice (327) and, as a married woman, she reads of the "Saviour's life and death" until she is brought to 
tears (329). Like Anne and Susan in “Lizzie Leigh” and David, Eleanor, and (eventually) Nest in “The Well”, she becomes the mediator between God's love and a fallen and proud humanity. Her Christ-like heroism is established at the story’s first moment of crisis when John finds her with Dick. John recalls how, on perceiving the stone that Dick was aiming at him, she instinctively "clung round me as a shield, making her sweet body a defense for mine” (329). ${ }^{5}$ Her subsequent disability removes the opposition that her marriage to John would have otherwise provoked. Throughout their marriage, her gentleness remains a guiding force and keeps John from "the great gulph" of sin that threatens to overwhelm him (331). Ultimately, it is her influence that enables him to forego his religious fanaticism and to play the part of the Good Samaritan, "befriend[ing]” his old enemy Dick when he appears at their door as a convict returned before his time (334).

Following “The Heart of John Middleton”, the eighteen other pieces that Gaskell contributed to Household Words over its nine-year publication history emphasize the significance of self-forgetful kindness in creating a community that is inter-dependent and resistant to the capitalist ethic of individualism and selfadvancement. However, it is the early pieces that are particularly significant in shaping the journal and in forming the expectations of readers. As this article has shown, Gaskell's attention to the content and features of biblical parable in the first three stories that she sent to Dickens generate an ethical space of encounter between text and reader and critique encroaching social norms. More significantly, they dramatize the lesson that it is only through "a better acquaintance and a kinder understanding” ("Preliminary Word” 1) that a sense of common humanity can be reached and the nation can be transformed. 
Notes

With thanks to Paisley Mann and Karen Laird who helped shape and direct my ideas for this article. Thanks also go to my colleague Valerie Purton who read through the article and offered invaluable encouragement.

\footnotetext{
${ }^{1}$ Mary-Catherine Harrison draws on the work of Elaine Scarry and William James to explain the rationale behind the anxiety that emotional responses to art "do not prompt, and might even deter, ethical behaviors in the real world” (260).

${ }^{2}$ I have used the Dickens Journals Online Database (www.djo.org.uk) to ascertain the authors of the anonymous Household Words texts. I have also gathered bibliographic details from Anne Lohrli's Household Words.

3 “Libbie Marsh's Three Eras” first appeared in Howitt's Journal of Literature and Progress in June 1847.

${ }^{4}$ Jenny Uglow describes Gaskell's ambivalence towards Martineau as a man and her suspicion of his "charismatic power." (131-2). In "Traits and Stories of the Huguenots," a piece of imaginative non-fiction that she wrote for Household Words in 1853, Gaskell comments on how the Martineaus are descended from the Huguenot stock; from "active strong men, full of good sense and practical talent” (353).

${ }^{5}$ Alan Shelston notes how this scene is re-worked in North and South when "Margaret Hale steps in front of John Thornton to protect him from the millworkers' missiles.” The Works of Elizabeth Gaskell. Vol. 1. Ed. Alan Shelston. London: Pickering \& Chatto, 2005, 177.
}

\section{Works Cited}

[Bennett, William Cox] “The Seasons.” Household Words 3 (13 March 1850): 65.

Carpenter, Mary. Morning and Evening Meditations: For Every Day in a Month. London: P.P. Carpenter, 1850.

Colòn, Susan E. Victorian Parables. London; New York: Continuum, 2012.

Cote, Amy. "Parables and Unitarianism in Elizabeth Gaskell’s Mary Barton." Victorian Review 40.1 (2014): 00-00.

Cunningham, Valentine. "Dickens and Christianity.” A Companion to Charles Dickens. Ed. David Paroissien. Oxford: Wiley-Blackwell, 2011. 255-76.

Davis, Lennard. Enforcing Normalcy: Disability, Deafness, and the Body. London: Verso, 1995.

Dickens, Charles. The Letters of Charles Dickens. Vol. 6, 1850-1852. Ed. Graham Storey, Kathleen Tillotson and Nina Burgis. Oxford: Clarendon Pilgrim, 1998.

— “A Walk in a Workhouse.” Household Words 9 (25 May 1850): 204-7.

— "Pet Prisoners.” Household Words 5 (27 April 1850): 97-103.

— “A Child's Dream of a Star.” Household Words 2 (6 April 1850): 25-6.

- [and W.H. Wills] "Valentine’s Day at the Post-Office.” Household Words 1 (30 March 1850): 6-12.

— “A Preliminary Word.” Household Words 1 (30 March 1850): 1-2.

Gaskell, Elizabeth. Mary Barton. Ed. Shirley Foster. Oxford: Oxford University Press, 2006.

- Further Letters of Mrs Gaskell. Ed. J.A.V Chapple and Arthur Pollard. Manchester: Manchester, 2003. 
- Ruth. Ed. Alan Shelston. Oxford: Oxford University Press, 1998.

- The Letters of Mrs. Gaskell. Ed. J.A.V. Chapple and Arthur Pollard. Manchester: Manchester University Press, 1996.

— “Libbie Marsh’s Three Eras,” Lizzie Leigh and Other Tales. Cheap Edition. London: Chapman and Hall, 1855: 235-256.

— “Traits and Stories of the Huguenots.” Household Words 194 (10 Sep 1853): 348-354.

— “ “The Heart of John Middleton.” Household Words 40 (28 Dec 1850): 325334.

— “The Pen of Well Morfa.” Household Words 34-5 (16 and 23 Nov 1850): 1826; 205-210.

— “Lizzie Leigh.” Household Words 1-3 (30 March, 7 and 13 April 1850): 1-6; 32-5; 60-5.

[Griffiths, Eliza] “The Dumb Girl.” Household Words 35 (23 Nov 1850): 205.

[Harper, Mr.] “The Chords of Love.” Household Words 40 (28 Dec 1850): 334.

Harrison, Mary-Catherine. "The Paradox of Fiction and the Ethics of Empathy: Reconceiving Dickens’s Realism.” Narrative 16.3 (2008): 256-278.

Huett, Lorna. “Among the Unknown Public: Household Words, All the Year Round and the Mass-Market Weekly Periodical in the Mid-Nineteenth Century." Victorian Periodicals Review 38.1 (2005): 61-82.

Hughes, Linda K., and Michael Lund. Victorian Publishing and Mrs Gaskell's Work. Charlottesville: University Press of Virginia, 1999.

Jameson, Anna. Sacred and Legendary Art, 2 vols. London: Longmans, 1848.

King, Joshua. “John Keble’s The Christian Year: Private Reading and Imagined National Religious Community.” Victorian Literature and Culture 40 (2012): 397-420.

Keen, Suzanne. Empathy and the Novel. New York: Oxford University Press, 2007

Krueger, Christine L. The Reader's Repentance: Women Preachers, Women Writers, and Nineteenth-Century Social Discourse. Chicago: University of Chicago Press, 1992.

Larsen, Timothy. A People of One Book: The Bible and the Victorians. Oxford: Oxford University Press, 2011.

Lohrli, Anne. Household Words: A Weekly Journal 1850-1859 Conducted by Charles Dickens. Toronto: University of Toronto Press, 1974.

[Knight Hunt, Frederick] “What a London Curate Can Do if He Tries.” Household Words 34 (16 November 1850): 172-6.

[Meredith, George] “New Year’s Eve.” Household Words 40 (28 December 1850): 325

[Morley, Henry] "Views of the Country." Household Words 34 (16 November 1850): 169-72.

Morris, Emily Jane. “'Ready to hear and to help’: Female Agency and the Reclaimation of the Fallen Woman in Elizabeth Gaskell's 'Lizzie Leigh.'” The Gaskell Journal 23 (2009): 40-53.

Recchio, Thomas. Elizabeth Gaskell's Cranford: A Publishing History. Aldershot and Burlington: Ashgate, 2009.

Reitz, Caroline. "Household Style: Dickens Edits a Nation.” English: Journal of the English Association 62 (2013): 22-46

Singleton, Jon. "The Dissonant Bible Quotation: Political and Narrative Dissention in Gaskell’s Mary Barton.” ELH 78 (2011): 917-41. 
Styler, Rebecca. “The Problem of 'Evil' in Elizabeth Gaskell's Gothic Tales.” Gothic Studies 12 (2010): 33-50.

Uglow, Jenny. Elizabeth Gaskell: A Habit of Stories. London: Faber and Faber, 1993.

Waters, Catherine. Commodity Culture in Dickens's Household Words: The Social Life of Goods. Aldershot: Ashgate, 2008.

Webb, R.K. "The Gaskells as Unitarians.” Dickens and Other Victorians. Ed. Joanne Shattock. London: Macmillan, 1998. 144-71.

[Weir, William]. "William Wordsworth.” Household Words 9 (25 May 1850), 210-11.

[Weir, William and W. H. Wills]. "Short Cuts across the Globe." Household Words 3 (13 April 1850), 65-8. 